\title{
SYNTHESIS AND CHARACTERIZATION OF GREENER CERAMIC MATERIALS WITH LOWER THERMAL CONDUCTIVITY USING OLIVE MILL SOLID BYPRODUCT
}

\author{
Xenofon Spiliotis ${ }^{1}$ \\ Vayos Karayannis \\ Department of Chemical Engineering \\ University of Western Macedonia \\ 3 Ikaron str., Kozani, Greece, 50100 \\ vkarayan62@gmail.com \\ Stylianos Lamprakopoulos ${ }^{1}$ \\ Konstantinos Ntampegliotis ${ }^{1}$ \\ George Papapolymerou \\ ${ }^{1}$ Department of Environment \\ University of Thessaly \\ Gaiopolis Campus, Larissa, Greece, 41110
}

\begin{abstract}
In the current research, the valorization of olive mill solid waste as beneficial admixture into clay bodies for developing greener ceramic materials with lower thermal conductivity, thus with increased thermal insulation capacity towards energy savings, is investigated. Various clay/waste mixtures were prepared. The raw material mixtures were characterized and subjected to thermal gravimetric analysis, in order to optimize the mineral composition and maintain calcium and magnesium oxides content to a minimum. Test specimens were formed employing extrusion and then sintering procedure at different peak temperatures. Apparent density, water absorption capability, mechanical strength, porosity and thermal conductivity were determined on sintered specimens and examined in relation to the waste percentage and sintering temperature. The experimental results showed that ceramic production from clay/olive-mill solid waste mixtures is feasible. In fact, the mechanical properties are not significantly impacted with the incorporation of the waste in the ceramic body. However, the thermal conductivity decreases significantly, which can be of particular interest for thermal insulating materials development. Furthermore, the shape of the produced ceramics does not appear to change with the sintering temperature increase.
\end{abstract}

Keywords: ceramics, green materials, circular economy, olive mill solid waste, porosity, thermal conductivity, thermal insulation.

\section{Introduction}

Innovative technologies that incorporate different forms of biomass and other alternative solid products (produced from various waste treatments) into red ceramics seem to develop rapidly at a global level. Actually, biomass energy potential is addressed to be the most promising among the renewable energy sources, due to its spread and availability worldwide [1-3]. The interesting points in these technologies are that they:

a) can act as an efficient disposal method;

b) exploit the biomass energy content into clay bodies for fuel savings;

c) use of materials with organic matter as pore-forming agents [4, 5].

Olive-mill solid waste is the main waste produced during the process of olive-pomace oil production. Particularly in Greece, approximately 250,000 tons of (olive stone wooden residue (OSWR) are produced annually [6, 7]. OSWR is mainly used as alternative fuel due to its high calorific value $(18,828-20,577 \mathrm{MJ} / \mathrm{Kg})[8,9]$. 
Introduction of olive-mill solid residue into clay-based ceramics can be considered as a promising alternative solution for the valorization of this solid residue. Effluent olive-mill wastewater sludge was already embedded into fired laboratory produced clay bricks by Hamza et al. [10]. Moreover, Cotes Palomino et al. [11, 12] have studied the influence of the amount of wet pomace (containing water, olive stone and pulp residue) into ceramics materials for optimization of their technological properties in order to meet the standards for use as structural construction bricks. Actually, the addition of olive-mill solid residue as a pore-forming agent into ceramic brick clays must be carefully controlled. High \% addition into the ceramic body will liberate heat at an excessive rate and localized heating may cause defects in the products [13].

The aim of the present research is to provide broader insight into ceramic microstructures elaborated starting from standard industrial ceramic clays and OSWR powder, in the context of circular economy towards sustainable development. Emphasis is placed on the development of greener ceramic materials with lower thermal conductivity, thus focusing on the potential for improved thermal insulation capabilities with the beneficial utilization of this solid residue as admixture into ceramics. Particularly, the decomposition of OSWR in the ceramic body upon sintering is expected to influence the porosity and consequently the thermal conductivity of the produced ceramic material.

\section{Materials and methods}

\section{1. Raw Materials}

\section{1. 1. Chemical Analysis}

The 'Viokeral' clay mixture used in the present study is a blending at certain proportions of three clays collected from various locations of Central Greece and provided by "TERRA S.A.". Table 1 contains chemical analysis results of these clays.

Table 1

Chemical analysis of clays*

\begin{tabular}{|c|c|c|c|}
\hline \multirow{2}{*}{ PARAMETER } & \multicolumn{3}{|c|}{ CONSTITUENT CLAY (\%) } \\
\hline & $\mathbf{A}$ & B & $\mathbf{C}$ \\
\hline L.O.I.** & 11.95 & 9.87 & 16.54 \\
\hline $\mathrm{SiO}_{2}$ & 49.40 & 52.79 & 51.02 \\
\hline $\mathrm{Al}_{2} \mathrm{O}_{3}$ & 12.89 & 13.53 & 8.55 \\
\hline $\mathrm{Fe}_{2} \mathrm{O}_{3}$ & 7.10 & 7.57 & 4.66 \\
\hline $\mathrm{CaO}$ & 8.58 & 6.29 & 11.62 \\
\hline $\mathrm{MgO}$ & 4.86 & 4.31 & 3.89 \\
\hline $\mathrm{K}_{2} \mathrm{O}$ & 2.88 & 3.19 & 1.55 \\
\hline $\mathrm{Na}_{2} \mathrm{O}$ & 1.56 & 1.57 & 1.42 \\
\hline $\mathrm{TiO}_{2}$ & 0.818 & 0.855 & 0.621 \\
\hline $\mathrm{CaCO}_{3}(\mathrm{eq})$ & 14.72 & - & 24.46 \\
\hline $\mathrm{CO}_{2}$ & 6.47 & - & 10.75 \\
\hline
\end{tabular}

Note: *-source: TERRA S. A.; **-L.O.I.=Loss on Ignition

OSWR is the main residue of olive-pomace oil production processes. The OSWR used in the present study was obtained from a local olive press treatment plant after dewatering. Table 2 presents physicochemical analysis results for this OSWR while Table 3 shows a typical physicochemical analysis of OSWR. 
Table 2

Physicochemical Analysis of OSWR*

\begin{tabular}{ccc}
\hline & Physical characteristics \\
\hline Net Calorific Value & $17,818 \mathrm{MJ} / \mathrm{kg}$ \\
Gross Calorific Value & $19,269 \mathrm{MJ} / \mathrm{kg}$ \\
\hline & Chemical characteristics \\
\hline Carbon & $48.68 \% \mathrm{w} / \mathrm{w}$ \\
Hydrogen & $6.84 \% \mathrm{w} / \mathrm{w}$
\end{tabular}

Note: *-source: TERRA S.A.

Table 3

Physicochemical Analysis of OSWR*

\begin{tabular}{cc}
\hline & Physical characteristics \\
\hline Gross Calorific Value** & $20,962 \mathrm{MJ} / \mathrm{kg}$ \\
Moisture & $12.3 \% \mathrm{w} / \mathrm{w}$ \\
Ash & $1.9 \% \mathrm{w} / \mathrm{w}$ \\
Combustibles*** & $85.8 \% \mathrm{w} / \mathrm{w}$ \\
\hline & Chemical characteristics \\
\hline Carbon & $48.59 \% \mathrm{w} / \mathrm{w}$ \\
Hydrogen & $5.73 \% \mathrm{w} / \mathrm{w}$ \\
Oxygen & $44.06 \% \mathrm{w} / \mathrm{w}$ \\
Nitrogen & $1.57 \% \mathrm{w} / \mathrm{w}$ \\
Sulphur & $0.05 \% \mathrm{w} / \mathrm{w}$
\end{tabular}

Note: * - Source: 1) Laboratory of Applied Thermodynamics; 2) Process design Laboratory, Aristotle University of Thessaloniki; **-Dry basis; *** - Wet basis

An advantage of OSWR is that $\mathrm{CO}_{2}$ emissions for this additive come from the biomass (free of calcium carbonate), which means that, regarding $\mathrm{CO}_{2}$ emission trading, this is a way to reduce the assigned quantities of $\mathrm{CO}_{2}$ and lower the carbon footprint, because biomass is weighed with a zero emission factor [14].

\section{1. 2. Thermal Analysis}

Fig. 1 shows the thermal analysis results, specifically TGA/DTA curves (Setaram STA 1600), for the "Viokeral" clay mixture. In these curves, it is observed that up to $150{ }^{\circ} \mathrm{C}$, release of hygroscopic water is taking place and the process is endothermic. From $155^{\circ} \mathrm{C}$ to $425^{\circ} \mathrm{C}$, loss of molecular water takes place and the process is also endothermic. From $425^{\circ} \mathrm{C}$ to $775{ }^{\circ} \mathrm{C}$, several endothermic and exothermic peaks are noticed due to combined dehydroxylation of the silicate lattice, combustion of organic matter and decomposition reactions [15]. From $775{ }^{\circ} \mathrm{C}$ to $858^{\circ} \mathrm{C}$, the process is endothermic due to the dissociation of carbonates. According to these results, the "Viokeral" mixture does not belong to the Kaolinitic group, since the characteristic peak of the kaolinic clays at about $980{ }^{\circ} \mathrm{C}$ is absent. The mass loss upon clay sintering at $1105{ }^{\circ} \mathrm{C}$ reaches $11.9 \% \mathrm{w} / \mathrm{w}$, which may be attributed to the elimination of organic matter by combustion, the elimination of water due to dehydroxylation, and the decomposition of carbonates.

In Fig. 2, the TGA/DTA curves for the OSWR used are presented. In these curves, the following endothermic and exothermic regions are noticed:

1) Up to $152.7^{\circ} \mathrm{C}$ : Dehydration (endothermic);

2) $152.7-438^{\circ} \mathrm{C}$ : Combustion of organic matter - Dehydration (endothermic);

3) $438-575^{\circ} \mathrm{C}$ : Combustion of organic matter (exothermic);

4) $575-649^{\circ} \mathrm{C}$ : Combustion of organic matter (endothermic);

5) $649-682.8^{\circ} \mathrm{C}$ : Combustion of organic matter (strongly exothermic). 


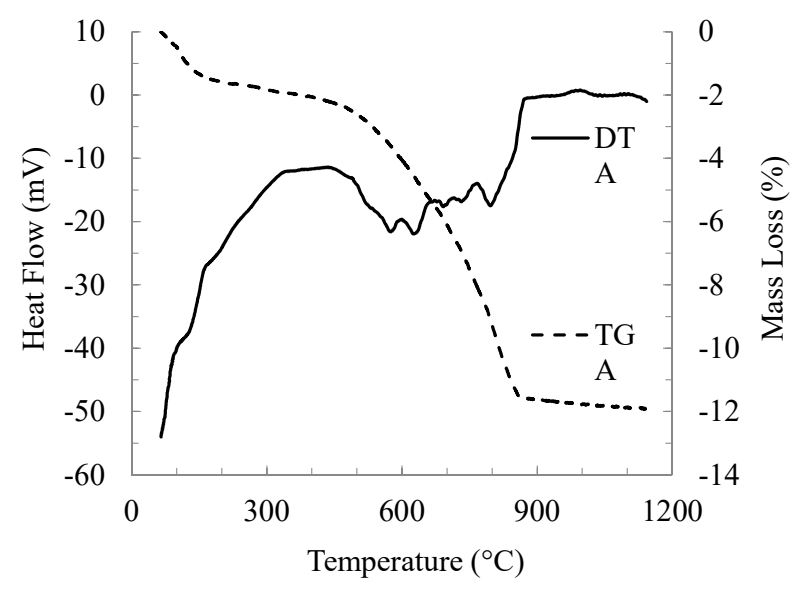

Fig. 1. DTA/TGA curves for the "Viokeral" clay mixture

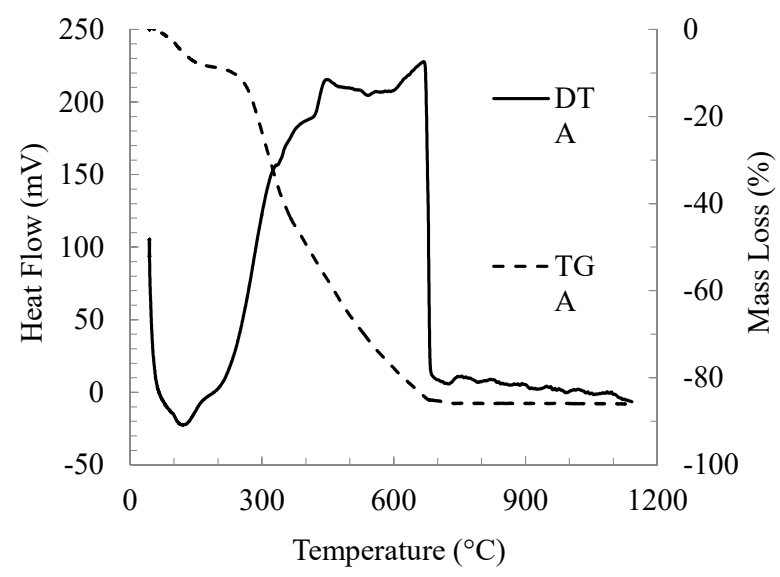

Fig. 2. TGA/DTA curves for OSWR

In Fig. 3, the TGA/DTA curves for the "Viokeral"/6 \%w/w OSWR mixture are provided.

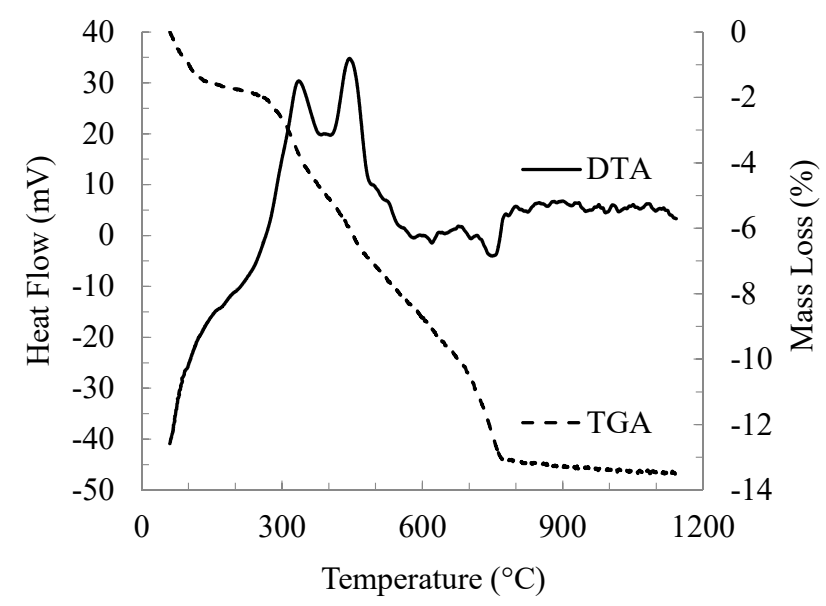

Fig. 3. TGA/DTA curves for "Viokeral"/6 \%w/w OSWR mixture

In these curves (Fig. 3), the following endothermic and exothermic regions are noticed:

1) Up to $110^{\circ} \mathrm{C}$ : Dehydration (endothermic);

2) $110-322.27^{\circ} \mathrm{C}$ : Loss of molecular water (endothermic);

3) $322.3-383.6^{\circ} \mathrm{C}$ : Loss of molecular water - Combustion of organic matter (exothermic); 
4) 383.6-434.3 ${ }^{\circ} \mathrm{C}$ : Loss of molecular water - Combustion of organic matter (endothermic);

5) 434.3-723.7 ${ }^{\circ} \mathrm{C}$ : Combustion of organic matter (exothermic);

6) $723.69-774{ }^{\circ} \mathrm{C}$ : Dissociation of carbonates (endothermic).

\section{2. Synthesis of ceramic specimens}

Ceramic bodies were produced using each time 0, 3, 6 and $9 \%$ w/w OSWR powder as an additive in the clay mixture. The various clay/OSWR mixtures were ground to particle size $<1 \mathrm{~mm}$. Then, they were kneaded with water and shaped into specimens using a laboratory pilot-plant vacuum extruder provided with manual cutter. The rectangular specimen cross section bars were $80 \times 43.5 \times 18 \mathrm{~mm}$. Extruded test pieces were optically checked and weighed for moisture determination using a thermos-balance. Subsequently, the specimens were first dried at room temperature for 12 hours and then in an oven at $110^{\circ} \mathrm{C}$ for at least 24 hours, until reaching a constant weight. Finally, the dried specimens were sintered in a programmable electric furnace following a protocol of gradual heating up to a peak temperature $(850,950$, 1050 or $1150{ }^{\circ} \mathrm{C}$ ).

A schematic diagram of the proposed method is shown in Fig. 4.

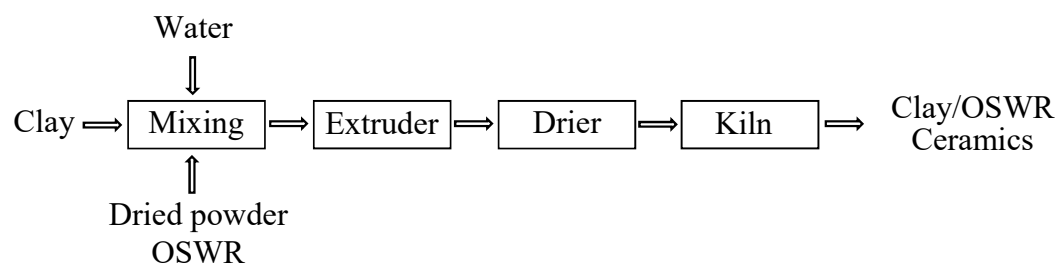

Fig. 4. Schematic diagram of the ceramic production process, using OSWR powder as admixture

\section{3. Characterization of ceramic specimens}

\section{3. 1. Water absorption capacity $\&$ open porosity}

The specimens were immersed in water $\left(25-30^{\circ} \mathrm{C}\right)$ for 24 hours. Water absorption (WA) capacity and open porosity (OP) are obtained from the following equations:

$$
\begin{aligned}
& W A(\%)=100 \frac{W_{w e t}-W_{d r y}}{W_{d r y}}, \\
& O P(\%)=100 \frac{W_{w e t}-W_{d r y}}{\rho V_{s}},
\end{aligned}
$$

where $W_{\text {wet }}$ - weight of saturated with water samples $(\mathrm{g}) ; W_{d r y}-$ weight of dry samples $(\mathrm{g}) ; \rho-$ density of water $\left(1 \mathrm{~g} / \mathrm{cm}^{3}\right) ; V_{s}$ - volume of the samples $\left(\mathrm{cm}^{3}\right)$.

\section{3. 2. Three-point bending strength (Modulus of Rupture)}

Strength of sintered specimens was determined upon three-point bending using a Universal Testing Machine (UTM) type INSTRON MTS 3382, and the Modulus of Rupture (MOR) was calculated from the following equation [16]:

$$
\operatorname{MOR}(\mathrm{MPa})=\frac{3 P L}{2 b w^{2}},
$$

where $P$ - force $(N) ; L$ - the opening width $(36 \mathrm{~mm}) ; b$ - width of sample $(\mathrm{mm}) ; w$ - thickness of the sample (mm). 


\section{3. 3. Thermal conductivity}

Thermal conductivity coefficient $(k)$ of sintered ceramics was measured at $25^{\circ} \mathrm{C}$ by applying the guarded heat flow meter method using an Anter Unitherm Model 2022.

\section{3. 4. Scanning Electron Microscopy (SEM) characterization}

SEM analysis of the ceramic specimens was conducted using a JEOL 6610LV microscope.

\section{Results}

\section{1. Mass loss on sintering and appearance color}

Fig. 5 depicts the weight loss and the consequent change of the bulk density of the specimens, as a result of the sintering process.

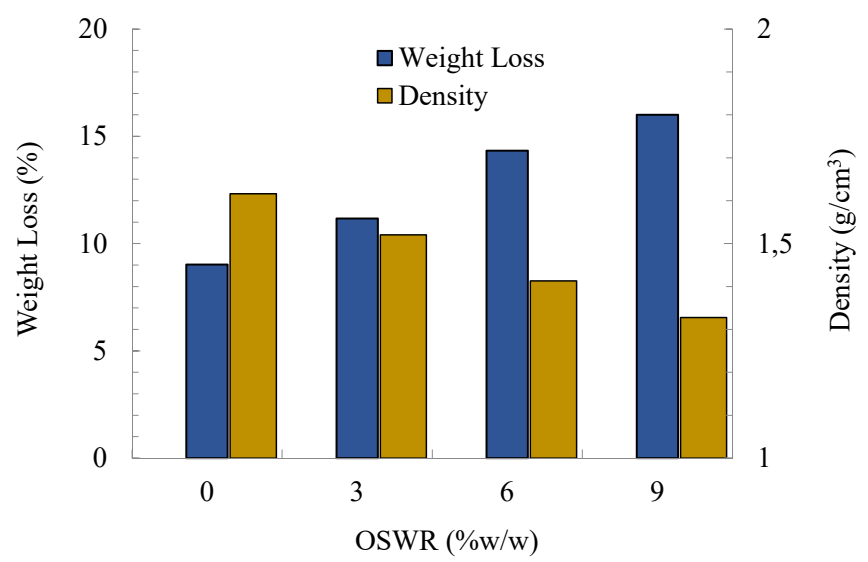

Fig. 5. Specimen weight loss and bulk density variation as a function of \% OSWR content due to the sintering process $\left(T_{\text {sint }}=950^{\circ} \mathrm{C}\right)$

\section{2. Water absorption capacity and open porosity}

In Fig. 6, the influence of the OSWR proportion in the clay/OSWR mixtures on the water absorption (WA) capacity and open porosity (OP) is shown.

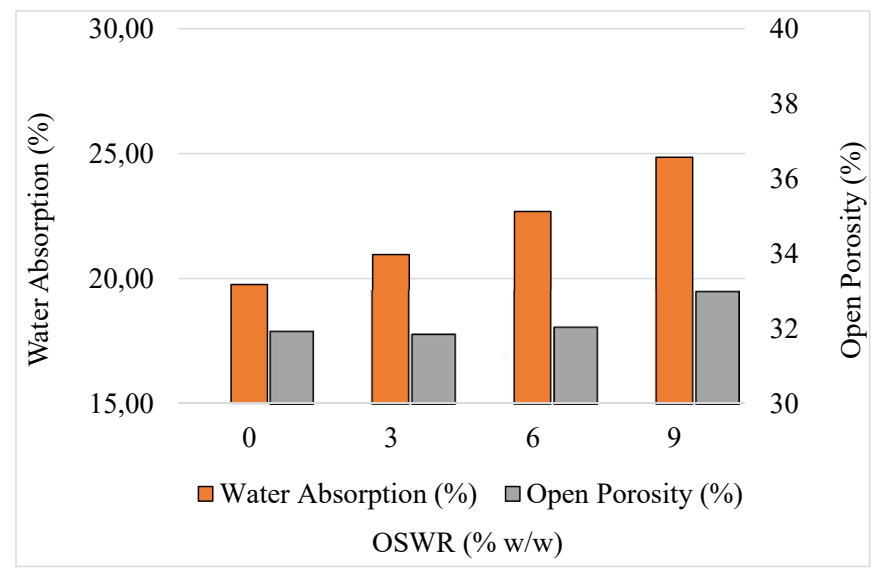

Fig. 6. Influence of the added OSWR percentage on Water Absorption (WA) and Open Porosity (OP) of sintered specimens $\left(T_{\text {sint }}=950^{\circ} \mathrm{C}\right)$

\section{3. Mechanical Strength (Modulus of Rupture - MOR)}

In Fig. 7, the dependence of mechanical strength calculated in terms of modulus of rupture (MOR) upon three-point bend testing of the specimens on the OSWR percentage in the clay/OSWR mixtures is presented. 


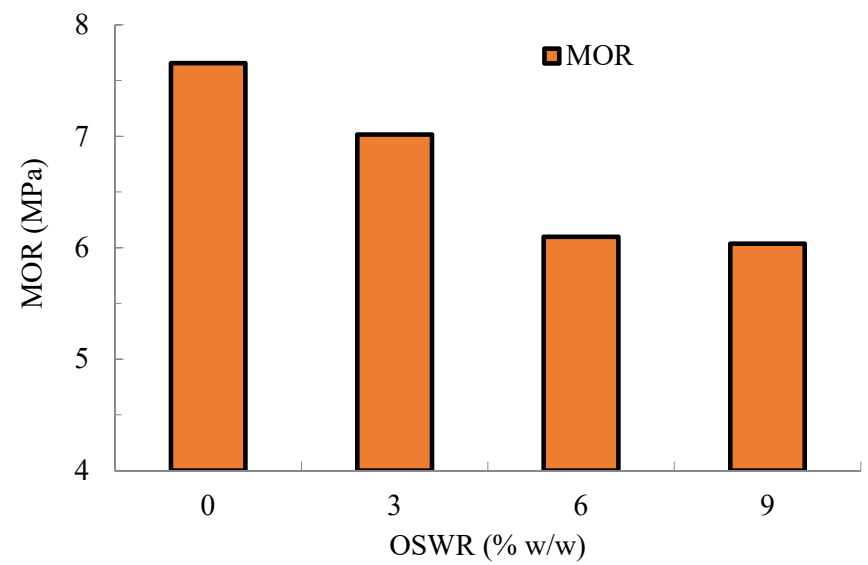

Fig. 7. Three-point bending strength (Modulus of Rupture - MOR) in relation to OSWR percentage in clay/OSWR mixtures, for sintered specimens $\left(T_{\text {sint }}=950{ }^{\circ} \mathrm{C}\right)$

In Fig. 8, the variation of MOR in relation to sintering temperature is shown.

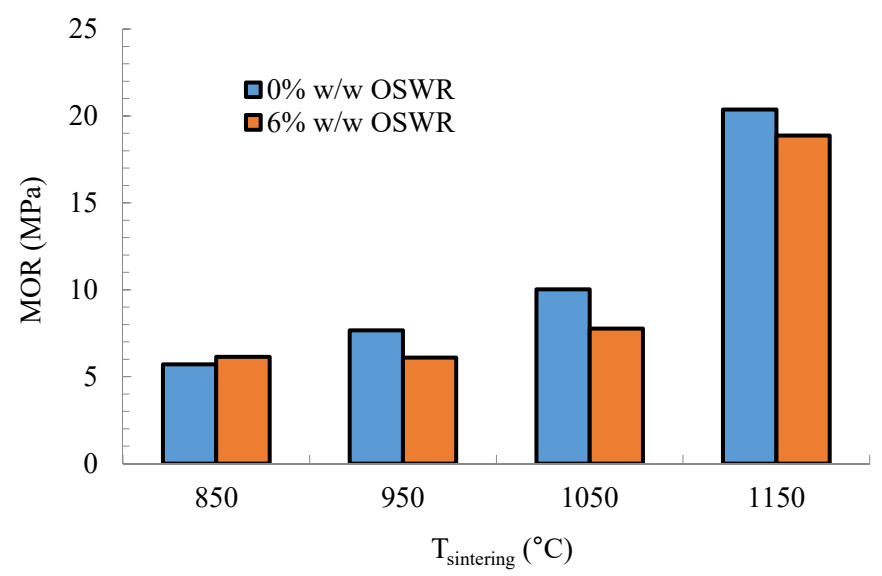

Fig. 8. MOR in relation to sintering temperature $(6 \% \mathrm{w} / \mathrm{w}$ OSWR content)

\section{4. Thermal conductivity}

In Fig. 9 the change in thermal conductivity coefficient in relation to $\% \mathrm{w} / \mathrm{w}$ OSWR in the clay/OSWR mixture is presented.

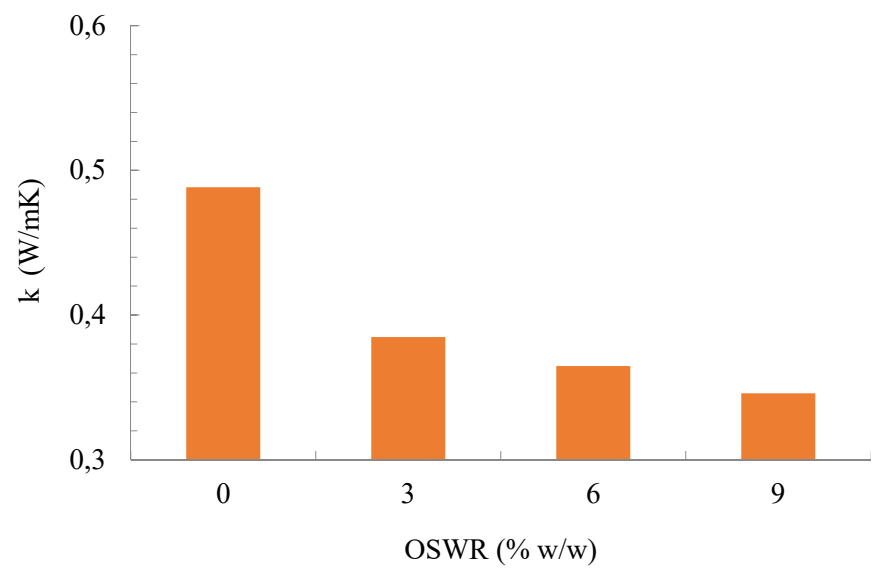

Fig. 9. Thermal conductivity coefficient $(k)$ at $25^{\circ} \mathrm{C}$ in relation to $\%$ OSWR addition, for sintered specimens $\left(T_{\text {sint }}=950^{\circ} \mathrm{C}\right)$ 
Fig. 10 depicts the effect of sintering temperature on thermal conductivity.

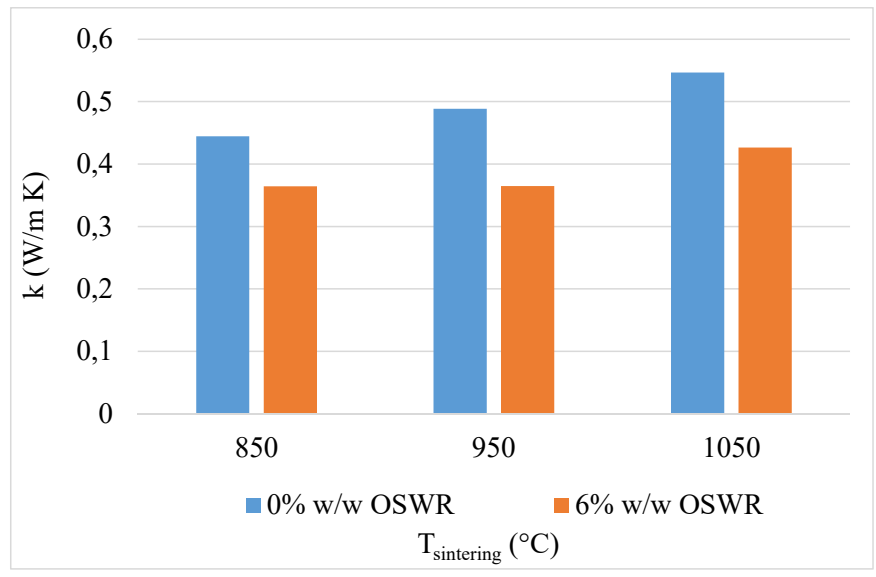

Fig. 10. Effect of sintering temperature on thermal conductivity coefficient $(k)$ at $25^{\circ} \mathrm{C}$

\section{5. Microstructure}

In Fig. 11, SEM micrographs of ceramic microstructures with $0-9 \%$ w/w OSWR content, obtained at $950{ }^{\circ} \mathrm{C}$, are presented. SEM micrographs of $6 \% \mathrm{w} / \mathrm{w}$ OSWR content microstructures produced at $850-1,150{ }^{\circ} \mathrm{C}$ are given in Fig. 12 to provide broader insight in the densification process.

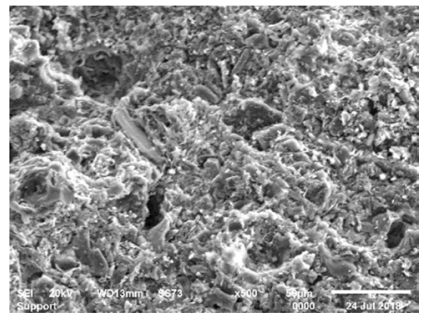

$a$

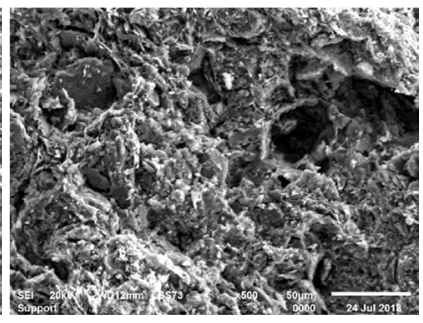

$b$

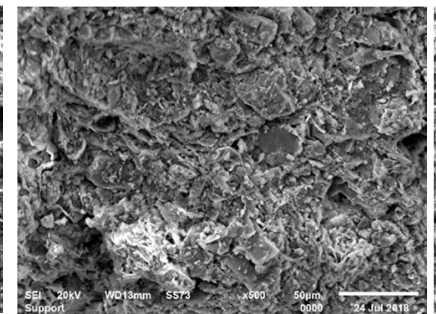

$c$

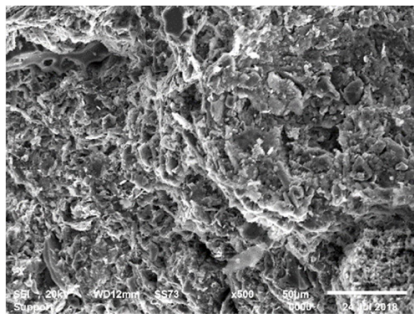

$d$

Fig. 11. Representative SEM micrographs of ceramic microstructures obtained at $950{ }^{\circ} \mathrm{C}$, incorporated with OSWR: $a-0 \% \mathrm{w} / \mathrm{w} ; b-3 \% \mathrm{w} / \mathrm{w} c-6 \% \mathrm{w} / \mathrm{w} ; d-9 \% \mathrm{w} / \mathrm{w}$

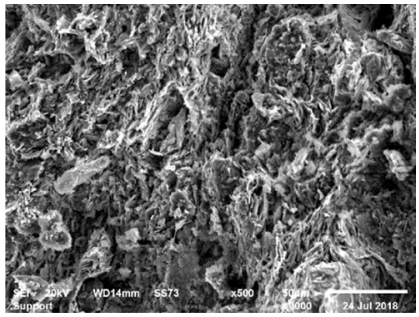

$a$

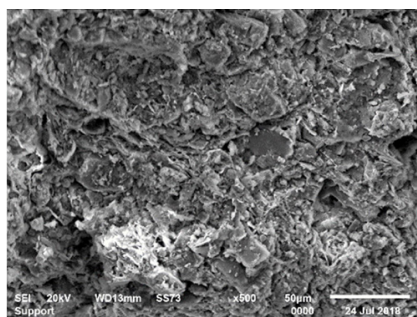

$b$

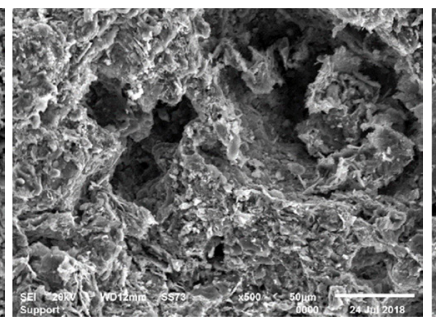

$c$

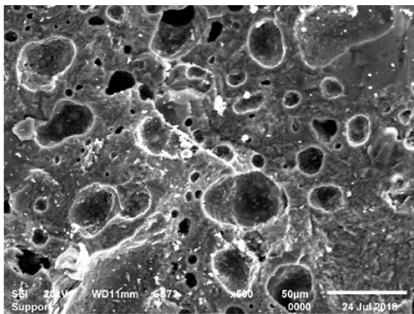

$d$

Fig. 12. Representative SEM micrographs of $6 \% \mathrm{w} / \mathrm{w}$ OSWR content ceramic microstructures obtained at: $a-850{ }^{\circ} \mathrm{C} ; b-950{ }^{\circ} \mathrm{C} ; c-1050{ }^{\circ} \mathrm{C} ; d-1150{ }^{\circ} \mathrm{C}$

In addition, photographs of real ceramic specimens, with OSWR $(6 \% \mathrm{w} / \mathrm{w})$ and without OSWR (prototype) are provided in Fig. 13. 


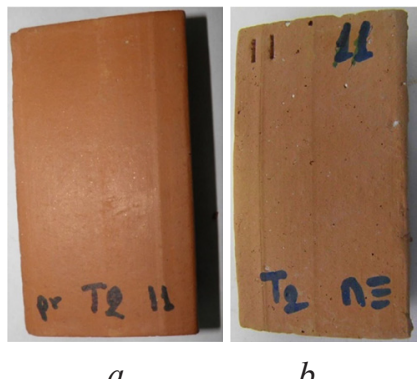

Fig. 13. Representative photographs of ceramic specimens obtained at $950{ }^{\circ} \mathrm{C}$, incorporated with OSWR: $a-0 \% \mathrm{w} / \mathrm{w}$ (prototype); $b-6 \% \mathrm{w} / \mathrm{w}$

\section{Discussion}

The experimental results (Fig. 5) showed that the sintering process causes significant weight loss, without significant change of the volume of the specimens. This results in an almost linear depletion of density with OSWR content increase. Raising the sintering temperature $\left(T_{\text {sint }}\right)$ from $850{ }^{\circ} \mathrm{C}$ up to $1050{ }^{\circ} \mathrm{C}$ does not affect either the outlook or the geometry of the specimens. At $T_{\text {sint }}=1150^{\circ} \mathrm{C}$ however, significant changes are observed: the color becomes dark brown, the texture vitreous and the samples almost waterproof (water absorption measurements confirm this observation), and also intense sample shrinkage occurs. Nevertheless, the specimen geometry is kept without any distortion, despite the large ratios of width/thickness $(>2.3)$ and length/thickness (>4.3). The observed weight loss is attributed to the loss of the added OSWR. In particular, for clay/OSWR $(6 \% \mathrm{w} / \mathrm{w})$ mixtures, the weight loss corresponds to more the $97 \%$ of the OSWR mass $\left(950{ }^{\circ} \mathrm{C}<T_{\text {sint }}<1050{ }^{\circ} \mathrm{C}\right)$ or more than $80 \%$ of the OSWR mass $\left(T_{\text {sint }}>1050{ }^{\circ} \mathrm{C}\right.$ or $\left.T_{\text {sint }}<950{ }^{\circ} \mathrm{C}\right)$. The above observations confirm that OSWR can act as pore-forming agent. Moreover, increasing the OSWR content in the clay mixtures results in the weakening of the terracotta color of the specimens, which become paler.

Water absorption capacity (WA) and open porosity (OP) of the ceramic specimens obtained (Fig. 6) do not change significantly as far as the OSWR percentage in clay/OSWR mixture is up to $6 \% \mathrm{w} / \mathrm{w}$. A noteworthy increase in the parameters under study seems to occur for $9 \% \mathrm{w} / \mathrm{W}$ OSWR use. It can, therefore, be assumed that, for clay/ OSWR mixtures with up to $6 \% \mathrm{w} / \mathrm{w}$ OSWR content, formation of closed pores is possibly favored (significant weight loss but stable water absorption).

With regard to bending strength (Fig. 7), for OSWR up to $6 \% \mathrm{w} / \mathrm{w}$ in the clay/OSWR mixture, the modulus of rupture (MOR) of the sintered specimens is reduced by approximately $20 \%$ compared to those produced from clay $(0 \% \mathrm{w} / \mathrm{w}$ OSWR). This trend seems to decelerate significantly for OSWR percentages higher than $6 \% \mathrm{w} / \mathrm{w}$. Moreover, raising firing temperature from $850{ }^{\circ} \mathrm{C}$ to $950{ }^{\circ} \mathrm{C}$ (Fig. 8), the MOR remains stable. However, from $950{ }^{\circ} \mathrm{C}$ to $1050{ }^{\circ} \mathrm{C}$, the MOR increases by approximately $27 \%$, while for sintering temperatures above $1050{ }^{\circ} \mathrm{C}$, the MOR strongly increases (by approx. $140 \%$ up to $1150{ }^{\circ} \mathrm{C}$ ). For comparison, laboratory prepared samples of clay-bricks with us much as $6 \%$ olive-mill wastewater sludge were also reported to successfully undergo mechanical and environmental tests [10]. Savings of raw materials into ceramic samples incorporated with wet pomace from olive oil industry are further referenced in the scientific literature, with the best results obtained for $3 \mathrm{wt} \%$ addition $[11,12]$.

In the present research, especially the reduction of thermal conductivity by approx. $20 \%$ achieved for only $3 \% \mathrm{w} / \mathrm{w}$ OSWR addition in the clay mixture (Fig. 9) should be underlined. Indeed, for more than $3 \% \mathrm{w} / \mathrm{w}$ of OSWR, thermal conductivity is further decreased even to $30 \%$ for $9 \% \mathrm{w} / \mathrm{w}$ OSWR. This means that even small quantities of OSWR in the clay mixture lead to increased porosity thus improving considerably the heat transfer resistance of the ceramic material produced. For $6 \% \mathrm{w} / \mathrm{w}$ OSWR in the clay mixture, ceramic specimen thermal conductivity is reduced (Fig. 10) by $18.1 \%$ at $T_{\text {sint }}=850{ }^{\circ} \mathrm{C}$ and by $25.3 \%$ at $T_{\text {sint }}=950{ }^{\circ} \mathrm{C}$, while, at $1,050{ }^{\circ} \mathrm{C}$, a more pronounced reduction in specimen thermal conductivity is observed. This means that the incorporation of the pore-making agent OSWR into ceramic bricks promotes the 
insulating properties even at lower sintering temperatures and much more at higher temperatures. These findings can be of particular importance for the development of thermal insulating ceramic materials.

Beyond the beneficial effect of OSWR acting as pore-former in the bulk of the ceramic bodies, any possible impact on ceramics properties by using different sources and years of harvest of OSWR are rather considered negligible, given the limited residue percentages incorporated. In fact, the SEM examination of the specimens indicates a relatively limited effect of the incorporation of OSWR in the ceramic microstructures obtained, except of desirable increased porosity (Fig. 11). On the other hand, the microstructure becomes more compact by increasing the firing temperature from $850{ }^{\circ} \mathrm{C}$ to $1025^{\circ} \mathrm{C}$ (Fig. 12, a $-\boldsymbol{c}$ ). Indeed, by further raising the sintering temperature up to $1150{ }^{\circ} \mathrm{C}($ Fig. 12, $\boldsymbol{d})$ an extended diffusion involving viscous flow in the ceramic matrices produced is clearly shown, resulting in a certain decrease in porosity, thus, at least partially, explaining the above stated increase in modulus of rupture (MOR).

\section{Conclusions}

Adding OSWR (the main solid residue of olive-pomace oil production processes) into clay mixtures typically used by the ceramic industry for brick manufacturing does not hinder neither the extrusion, nor the drying and firing processes.

A decrease in the fired bulk density from approximately $1.62 \mathrm{~g} / \mathrm{cm}^{3}$ to $1.33 \mathrm{~g} / \mathrm{cm}^{3}$ is attained for an OSWR addition of $9 \%$ at $950{ }^{\circ} \mathrm{C}$. Mechanical (bending) strength is not modified significantly, when OSWR content does not exceed $3 \%$, while MOR is reduced by $20 \%$ when OSWR percentage attains $6 \%$, and this trend seems to decelerate furthermore at higher $\%$ OSWR contents. Nevertheless, by sintering at $850{ }^{\circ} \mathrm{C}$ or $950{ }^{\circ} \mathrm{C}$, the brick bending strength remains stable, while, at $1050{ }^{\circ} \mathrm{C}$, it increases by approximately $27 \%$, and much more at $1150{ }^{\circ} \mathrm{C}$.

Particularly, thermal conductivity of the produced ceramic bricks is reduced by as much as $21.2 \%$ for only $3 \%$ addition of OSWR into the clay mixture $\left(0.385 \mathrm{Wm}^{-1} \mathrm{~K}^{-1}\right)$, while the three point bending strength (M.O.R.) remains around $7 \mathrm{MPa}$.

In conclusion, beneficial utilization of OSWR can be attained in two ways:

a) production of high density bricks, at low \% addition of OSWR as a body fuel;

b) production of lower density bricks at OSWR percentages greater than $3 \%$, both as a body fuel and pore-former agent.

Hence, the valorization of an olive-oil industry by-product can be achieved, while the fired clay brick industry can benefit from lower fuel consumption during the manufacturing process. The novel and greener ceramics so-produced are almost equivalent to the traditional ones, while also exhibiting lower thermal conductivity thus increased thermal insulation capability.

\section{Acknowledgements}

The current research was supported by a grant from "Terra S.A.” Company, A' Industrial Area, Larissa, Greece.

\section{References}

[1] Ducom, G., Gautier, M., Pietraccini, M., Tagutchou, J.-P., Lebouil, D., Gourdon, R. (2020). Comparative analyses of three olive mill solid residues from different countries and processes for energy recovery by gasification. Renewable Energy, 145, 180-189. doi: https://doi.org/10.1016/j.renene.2019.05.116

[2] Zabaniotou, A. (2018). Redesigning a bioenergy sector in EU in the transition to circular waste-based Bioeconomy-A multidisciplinary review. Journal of Cleaner Production, 177, 197-206. doi: https://doi.org/10.1016/j.jclepro.2017.12.172

[3] Mudhoo, A., Torres-Mayanga, P. C., Forster-Carneiro, T., Sivagurunathan, P., Kumar, G., Komilis, D., Sánchez, A. (2018). A review of research trends in the enhancement of biomass-to-hydrogen conversion. Waste Management, 79, 580-594. doi: https://doi.org/10.1016/j.wasman.2018.08.028

[4] Wang, A., Zheng, Z., Li, R., Hu, D., Lu, Y., Luo, H., Yan, K. (2019). Biomass-derived porous carbon highly efficient for removal of $\mathrm{Pb}(\mathrm{II})$ and $\mathrm{Cd}(\mathrm{II})$. Green Energy \& Environment, 4 (4), 414-423. doi: https://doi.org/10.1016/j.gee.2019.05.002

[5] Demir, I. (2008). Effect of organic residues addition on the technological properties of clay bricks. Waste Management, 28 (3), 622-627. doi: https://doi.org/10.1016/j.wasman.2007.03.019 
[6] Vlyssides, A. G., Barampouti, E. M. P., Mai, S. T. (2007). Physical characteristics of olive stone wooden residues: possible bulking material for composting process. Biodegradation, 19 (2), 209-214. doi: https://doi.org/10.1007/s10532-007-9127-5

[7] Federici, F., Fava, F., Kalogerakis, N., Mantzavinos, D. (2009). Valorisation of agro-industrial by-products, effluents and waste: concept, opportunities and the case of olive mill wastewaters. Journal of Chemical Technology \& Biotechnology, 84 (6), 895-900. doi: https://doi.org/10.1002/jctb.2165

[8] De la Casa, J. A., Romero, I., Jiménez, J., Castro, E. (2012). Fired clay masonry units production incorporating two-phase olive mill waste (alperujo). Ceramics International, 38 (6), 5027-5037. doi: https://doi.org/10.1016/j.ceramint.2012.03.003

[9] Azbar, N., Bayram, A., Filibeli, A., Muezzinoglu, A., Sengul, F., Ozer, A. (2004). A Review of Waste Management Options in Olive Oil Production. Critical Reviews in Environmental Science and Technology, 34 (3), 209-247. doi: https:// doi.org/10.1080/10643380490279932

[10] Hamza, W., Eloussaief, M., Mekki, H., Benzina, M. (2013). Physicochemical Characterization and Valorization of Tunisian Olive Oil Mill Wastewater Sludge in Ceramic Product. Transactions of the Indian Ceramic Society, 72 (4), 233-240. doi: https:// doi.org/10.1080/0371750x.2013.870752

[11] Cotes Palomino, M. T., Martínez García, C., Iglesias Godino, F. J., Eliche Quesada, D., Corpas Iglesias, F. A. (2015). Study of the wet pomace as an additive in ceramic material. Desalination and Water Treatment, 57 (6), 2712-2718. doi: https://oi.org/ 10.1080/19443994.2015.1035678

[12] Cotes Palomino, M. T., Martínez García, C., Iglesias Godino, F. J., Eliche Quesada, D., Pérez Latorre, F. J., Calero de Hoces, F. M., Corpas Iglesias, F. A. (2015). Study of Waste from Two-Phase Olive Oil Extraction as an Additive in Ceramic Material. Key Engineering Materials, 663, 86-93. doi: https://doi.org/10.4028/www.scientific.net/kem.663.86

[13] Ruppik, M. (2006). Einsatz organischer und anorganischer Porosierungsstoffe in der Ziegelindustrie. Zi Ziegelindustrie international, 59 (8), 22-29.

[14] Commission Decision of 18 July 2007 establishing guidelines for the monitoring and reporting of greenhouse gas emissions pursuant to Directive 2003/87/EC of the European Parliament and of the Council (notified under document number C(2007) 3416) (Text with EEA relevance) (2007/589/EC). L229. Official Journal of the European Union. Available at: https://eur-lex.europa.eu/legal-content/EN/ALL/?uri=CELEX\%3A32007D0589

[15] Smykatz-Kloss, W. (1974). Differential Thermal Analysis, Applications and Results in Mineralogy - (Minerals and Rocks, Vol. II). Springer-Verlag, 185.

[16] Karayannis, V. G. (2016). Development of extruded and fired bricks with steel industry byproduct towards circular economy. Journal of Building Engineering, 7, 382-387. doi: https://doi.org/10.1016/j.jobe.2016.08.003

Received date 14.12.2019

Accepted date 10.01.2020

Published date 20.12.2019
(C) The Author(s) 2020

This is an open access article under the CC BY license (http://creativecommons.org/licenses/by/4.0). 